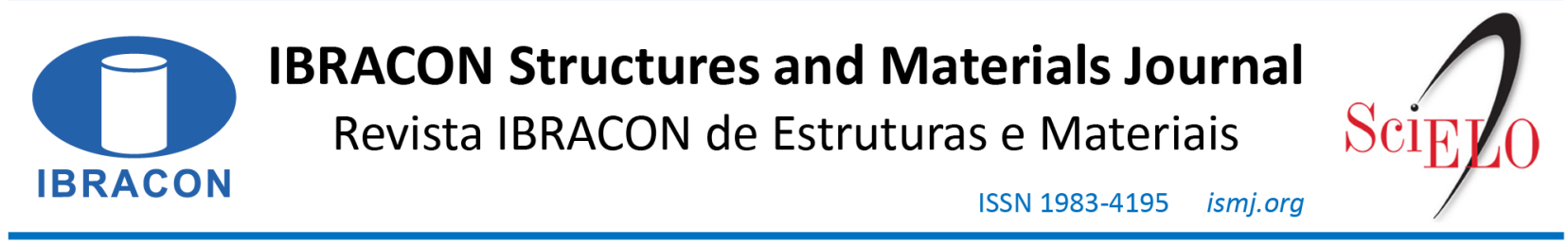

ORIGINAL ARTICLE

\title{
Experimental and numerical analysis of composite steel and concrete trusses
}

\section{Análise Numérica e Experimental de Treliças Mistas de Aço e Concreto}

Joel Donizete Martins ${ }^{\mathrm{a}}$ (D)

Sineval Esteves Pereira Junior ${ }^{\mathrm{b}}$ (D)

Ellen Martins Xavier ${ }^{\mathrm{C}}$ (D)

Luiz Henrique de Almeida Neiva ${ }^{\mathrm{c}}$ (D)

Arlene Maria Cunha Sarmanho ${ }^{c}$

${ }^{a}$ Instituto Federal Minas Gerais - IFMG, Campus Congonhas, Congonhas, MG, Brasil

bUniversidade Federal de São Carlos - UFSCar, Programa de Pós-graduação em Engenharia Civil - PPGECiv, São Carlos, SP, Brasil

${ }^{\mathrm{c}}$ Universidade Federal de Ouro Preto - UFOP, Programa de Pós-graduação em Engenharia Civil - PROPEC, Ouro Preto, MG, Brasil

Received 08 December 2017

Accepted 16 June 2020

\begin{abstract}
In the present work, two composite trusses formed by tubular shapes supporting a concrete slab were evaluated. Based on analytical formulation related to the problem, according to recommendations of standards, numerical analyses were performed, with models created using the software Ansys, and an experimental analysis with full-scale tests. Good agreement between the three analysis types was observed. A possible shear connection failure in one truss was observed. With a change in the second truss's connector length, an increase in the structure's strength and rigidity was achieved. In this study, because the shear connectors were directly welded on the upper chord wall, local effects with localized plastifications were evidenced.
\end{abstract}

Keywords: composite trusses, tubular connections.

Resumo: Neste trabalho foram avaliadas duas treliças mistas projetadas com perfis tubulares, associadas a uma laje maciça de concreto. Baseando-se em expressões analíticas relacionadas ao problema, seguindo as recomendações de normas, análises numéricas foram realizadas, com modelos criados utilizado o programa computacional Ansys e uma análise experimental, por meio de ensaios em laboratório com a estrutura em escala real. Houve boa aproximação dos resultados nas três análises, sendo observada a possibilidade de falha na conexão de cisalhamento em uma das treliças. Com uma mudança no comprimento do conector da segunda treliça, foi observado um aumento na resistência e na rigidez da estrutura. No estudo, ficaram evidentes os efeitos localizados da ligação entre os perfis em seção tubular e da fixação do conector de cisalhamento diretamente sobre a parede do banzo superior, que causaram plastificações também localizadas.

Palavras-chave: treliças mistas, ligações tubulares.

How to cite: J. D. Martins, S. E. Pereira Junior, E. M. Xavier, L. H. A. Neiva, and A. M. C. Sarmanho, "Experimental and numerical analysis of composite steel and concrete trusses," Rev. IBRACON Estrut. Mater., vol. 14, no. 2, e14201, 2021, https://doi.org/10.1590/S1983-

41952021000200001

\section{INTRODUCTION}

Lately, composite structures made of steel trusses and concrete slabs in bridge slabs and even buildings with large open spans have become more viable. The composite truss systems have proven to be very economical since they allow exploring each material's best characteristics. Due to the composite section bending, the greater compression values are concentrated in the slab, whereas the tension occurs in the lower chord. According to Wardenier et al. [1], in trusses designed without considering the composite section solution, $50 \%$ of the material weight used to fabricate the structure 
is concentrated in the compressed chord, $30 \%$ in the chord under tension, and $20 \%$ in the elements of the diagonals and vertical posts. Therefore, there can be a significant reduction in materials consumption when considering the composite section since the upper chord's dimensions can be reduced without influencing the structure capacity.

This study presents experimental and numerical analyses of composite trusses designed with tubular profiles associated with a concrete slab. The experimentally analyzed truss was donated to the Universidade Federal de Ouro Preto (UFOP). The analysis results are assessed to investigate the mechanisms used to ensure a better steel-concrete interaction, providing a behavior with most of the slab under compression. The steel is under tension, allowing a more efficient and secure composite section. Two truss models are numerically evaluated. For the first truss, numerical and experimental analyses were performed, and the results were compared to literature recommendations and standard code specifications. For the second truss, only numerical analyses were performed. The difference between Truss 1 and 2 is a change in the shear connection from Truss 1 to make the initially tested structure more efficient.

\section{THEORETICAL FOUNDATION}

Studies on composite trusses are still few, and most of them, including what is regulated by the Brazilian standards of steel and composite structures [2], were initially proposed in a publication of the 1980s (Chien and Ritchie [3]). According to these authors, composite trusses' design for the ultimate limit states is performed using a model considering sections plastification (Figure 1).

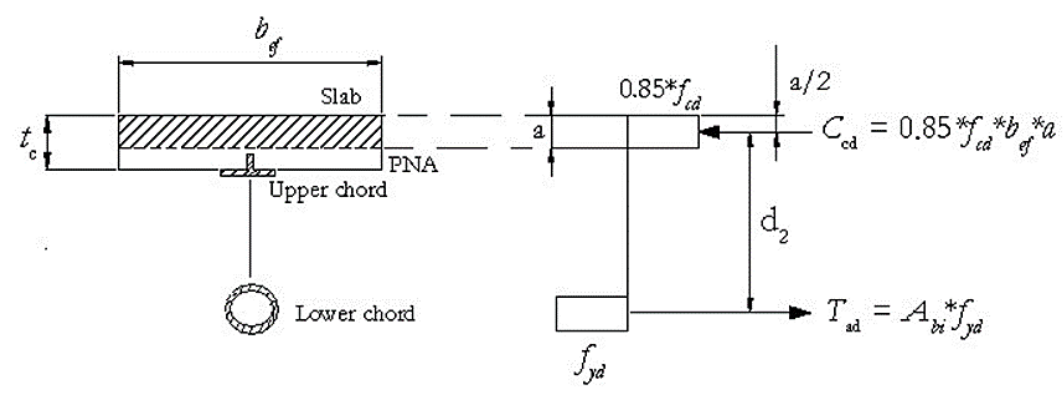

Figure 1. Model for global analysis of a composite truss under bending.

In this model, only the concrete slab and the lower chord are considered. The bending lever arm, $d_{2}$, formed between the concrete compression force and the tension force in the lower chord, is considered. The plastic neutral axis, PNA, must be positioned within the concrete slab in the Truss ultimate strength. Thus, the height of the plastic section $(a)$ must be lower than the slab thickness $\left(t_{c}\right)$. For a ductile rupture to occur, the lower chord section yielding stress $\left(T_{a d}\right)$ must occur before concrete crushing $\left(C_{c d}\right)$ and rupture of the shear connection $\left(Q_{r d}\right)$, also ensuring the total or complete interaction regime.

Concerning the other truss members, the diagonals are dimensioned to resist the total vertical shear load, while the upper chord is only considered in the analyses performed before concrete curing. However, this is a fundamental member in the composite section, even with the slab presence. It directly influences the shear connection behavior, especially when it comes to stress redistribution [4]. That is impaired in composite trusses because of stress concentration in the connecting nodes region, as demonstrated in Machacek and Cudejko [5] and Bouchair et al. [6]. Eurocode [7] proposes a methodology considering a non-uniform elastic distribution of stresses among the connectors. Such procedure is used in composite trusses whenever the plastic analysis of the connection may not be safe, as in bridges under fatigue or when the connectors are not ductile.

For serviceability limit states, when evaluating vertical displacements, it is recommended to calculate the structure stiffness considering the moment of inertia of the composite section, $I_{\text {mist }}$. That is made turning the concrete slab effective area into an equivalent area of steel, neglecting the concrete and the upper chord in the tension zone. To consider the effect of shear deformations on diagonal members, the effective moment of inertia, $I_{e f}$, must be calculated as Equation 1. $I_{m e t}$ is the cross section moment of inertia, considering only the truss steel members. This procedure is recommended by Chien and Ritchie [3] and is included in the Brazilian standard [2]. 
$I_{e f}=I_{m i s t}-0.15 I_{m e t}$

This moment of inertia is calculated considering the total interaction between the slab and the truss. The Canadian standard [8] presents Equation 2 to calculate the effective moment of inertia. The factor " $P$ " considers the degree of interaction between the slab and the truss. In the case of total interaction, this factor is considered equal to 1.0.

$I_{e f}=0.15 I_{m e t}+0.85 P^{0.25}\left(I_{\text {mist }}-0.15 I_{\text {met }}\right)$

According to Murray et al. [9], the standard reduction of $15 \%$ in the moment of inertia of the steel section can lead to good results when the relationship between the span length and the truss height $(L / h)$ has a value greater or equal to 15 . Therefore, the author proposes to consider a reduction factor, $C_{r}$, dependent on the ratio $(L / h)$ as shown in Equation 3 and to calculate the effective moment of inertia using Equation 4. From Murray et al. [9], this equation may lead to better results for $L / h<15$, rather than to consider the standard decrease of $15 \%$. In this case, the moment of inertia of the composite section, $I_{\text {mist }}$, must also be calculated to take the upper chord into account.

$C_{r}=0.9\left(1-e^{-0.28(L / h)}\right)^{2.8}$

$I_{e f}=\frac{1}{\frac{1-C_{r}}{C_{r} \cdot I_{m e t}}+\frac{1}{I_{m i s t}}}$

\section{NUMERICAL ANALYSIS}

\section{Definition of prototypes}

The trusses evaluated were designed to have an open span length of $10000 \mathrm{~mm}$ and its height equal to $1146 \mathrm{~mm}$ (Figure 2). Upright posts were used in the truss profiles with circular tubular hollow section on the diagonal members (CHS 101.6 x 6.4) and upright posts (CHS 60.2 x 6.4), and rectangular hollow section in the lower chord (RHS 150.0 x 120.0 x 6.4) and the upper chord (RHS 150.0 x 120.0 x 4.8). All these members were fabricated in VMB 300 steel $\left(f_{y}=300 \mathrm{MPa}\right)$. Due to the probability of the plastification occurring in the truss tubular connections, shell plates with a thickness of $12.5 \mathrm{~mm}$ were added at these points, as indicated in Figure $2 \mathrm{~b}$.

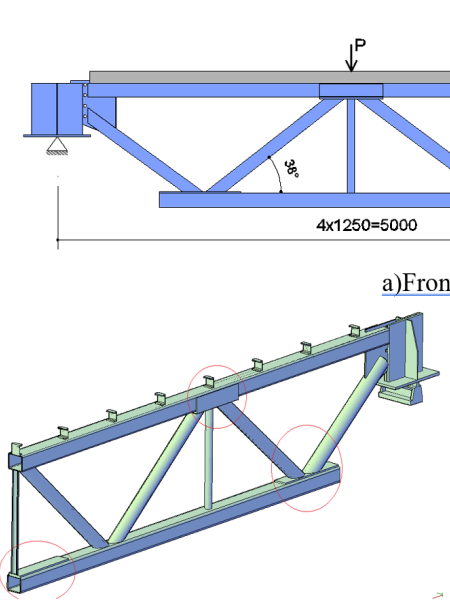

b) Perspective view of Truss 1

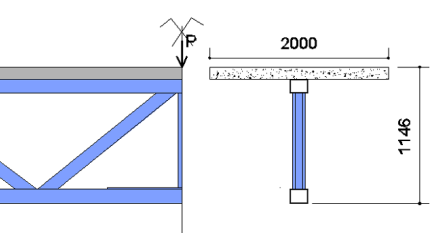

Frontal view

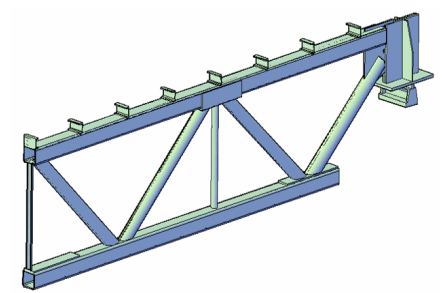

c) Perspective view of Truss 2

Figure 2. Configurations of the evaluated composite trusses. 
The slab was designed to a length equal to $2000 \mathrm{~mm}$, a thickness of $100 \mathrm{~mm}$, and concrete compressive strength, $f_{c k}$, of $25 \mathrm{MPa}$. In order to connect the slab to the upper chord, shear connectors were designed in a hot rolled U-profile (Figure $2 \mathrm{~b}$ ) with length $\left(l_{f c s}\right)$ equal to $80 \mathrm{~mm}$, web thickness $\left(t_{w c s}\right)$ equal to $4.32 \mathrm{~mm}$, and flange thickness $\left(t_{f c s}\right)$ equal to $6.9 \mathrm{~mm}$, made of ASTM A36 steel. The connectors were arranged along the chord with a $625 \mathrm{~mm}$ spacing.

Table 1. Results of the materials testing.

\begin{tabular}{cccc}
\hline Member & Yield strength (MPa) & Ultimate strength (MPa) & Compressive strength (MPa) \\
\hline Chords & 456 & 720 & - \\
\hline Diagonals & 442 & 930 & - \\
\hline Upright posts & 442 & 930 & - \\
\hline Shell plates & 350 & 450 & - \\
\hline Slab concrete & - & - & 25 \\
\hline
\end{tabular}

After the trusses were fabricated, the yielding strengths were obtained by experimental tests for the steel used in the chords, diagonals, reinforcement plates, and upright posts, according to Table 1. No characterization tests were performed in the steel of the shear connectors and the steel reinforcing bars. Thus, nominal values of yielding strength equal to $250 \mathrm{MPa}$ and $500 \mathrm{MPa}$, were considered in the analyses, respectively. The results showed that yield strength was higher than expected. Concerning the specific case of the chords' material, which is fundamental for determining the composite structure rupture limit, the tests showed a yield strength equal to $456 \mathrm{MPa}$, well above the expected $300 \mathrm{MPa}$. Thus, the ultimate limit turned out to be the shear connection rupture and not the lower chord yielding, as recommended in standards and predicted in the design. The composite truss would work in a partial interaction mode since the shear connection resistance ( $\Sigma Q_{r}$ ) presented a value smaller $(22 \%)$ than the tension axial load that causes the lower chord to yield by tension $\left(A_{b i} \cdot f_{y}\right)$.

A possible solution to avoid such a loss of interaction would be to increase the concrete strength or modify the shear connectors. However, these changes would negatively impact the fidelity of the evaluated prototypes to the initially designed structure, which would impair the research conclusions. It was then decided to evaluate the composite truss as it was initially conceived and to also model a second structure, modifying only the shear connection. In the composite Truss 2 , the shear connection was modified, using a connector of length $\left(l_{f c s}\right)$ extended to the end of the chord, with a width of $150 \mathrm{~mm}$, as shown in Figure 2c. This modification increases the connection resistance capacity because the connector is welded along the chord width, which will load the lateral side of the member, not only the top face when the connector is mobilized, providing more stiffness to its base.

\section{Numerical models design}

The numerical modeling was performed in the Ansys program using a three-dimensional analysis. For faster analysis, half of the truss was modeled due to its symmetry. The three-dimensional reinforced concrete finite element SOLID65 (Figure 3a) was used [10]. Although the internal reinforcing bar could be considered diffuse in the element SOLID65, it was decided to use independent elements for the reinforcement, which was modeled using the finite element LINK8 (Figure $3 \mathrm{~b}$ ). The slab mesh had nodes position coincided with the reinforcement nodes position, as shown in Figure 3c.

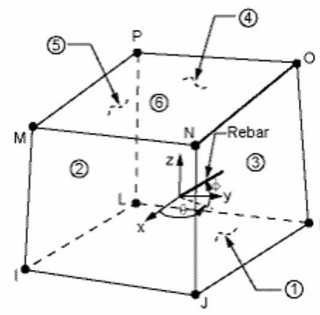

a) SOLID65. Source: [10]

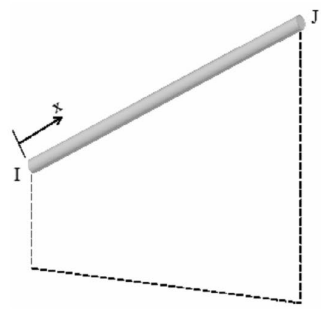

b) LINK8 Source: [10]

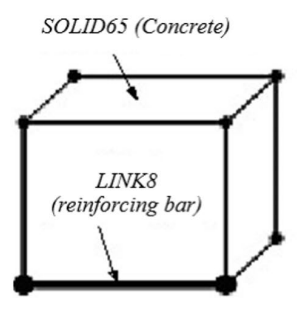

c) Connection between elements

Figure 3. Finite elements used in slab modeling. 
The modeling of the chords, diagonals, upright posts, and shear connectors was done using shell elements, SHELL181 (Figure 4a), allowing to consider localized effects in the connection nodes of the tubular section members. These elements were used in other studies involving tubular profiles with good results [11]. The modeling of the shell elements was done considering the dimensions of the cross-section midline of the tubular profiles. The connection of the slab with the shear connectors was made so that there was also a coincidence of node position of the finite elements of the slab and the shear connector elements, subsequently coupling these nodes, making for a rigid connection between the two structural elements, as shown in Figure 4b. Figure 5 shows a complete view of the model used.

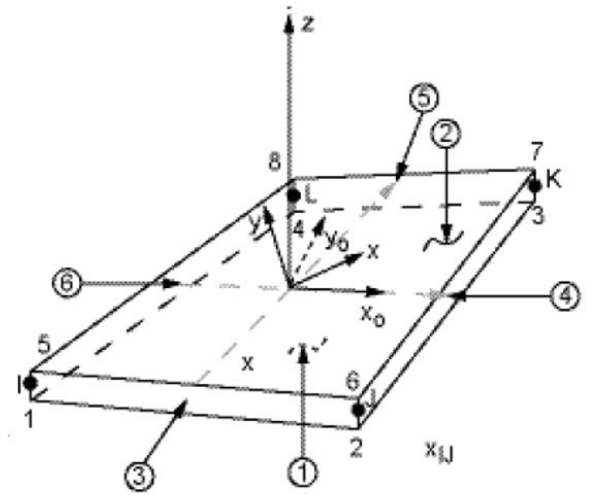

a) SHELL181 Source: [10]

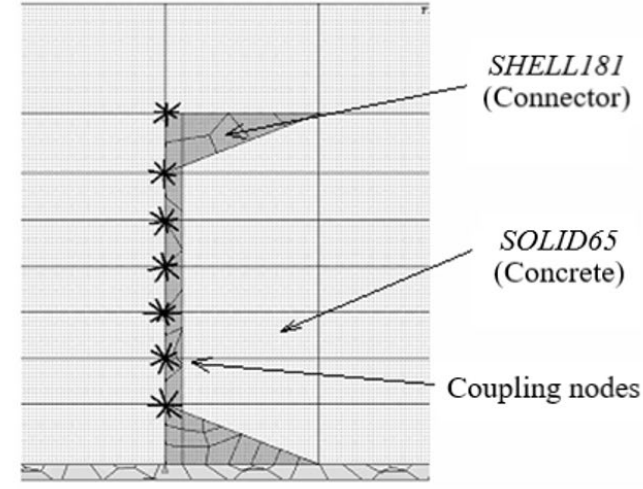

b) Coupling of nodes of different elements

Figure 4. Details of finite element SHELL181 and the coupling of nodes of slab elements and connectors.

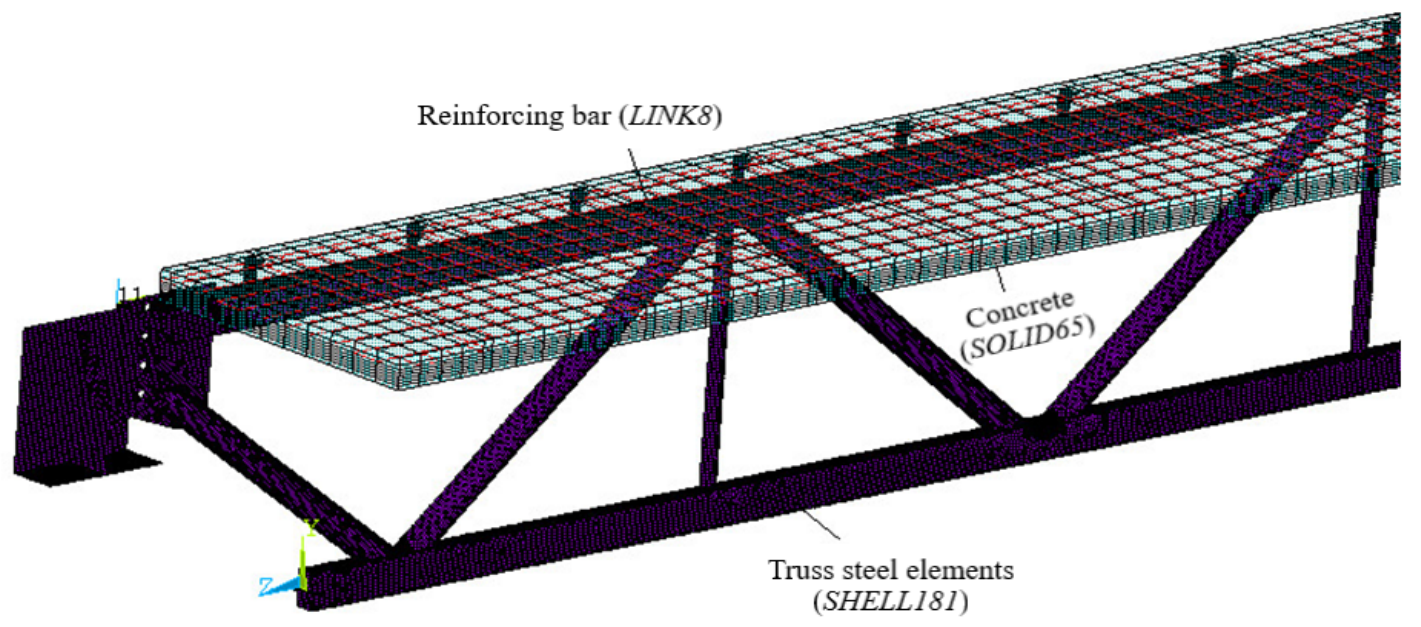

Figure 5. Overall view of the numerical model with members discretization.

A multilinear elastoplastic behavior with isotropic hardening was considered for the chords, upright posts, and diagonals to consider the materials mechanical properties extrapolating the elastic limit (Figure 6). For the truss steel members, stress versus strain curves considered the experimental data (Table 1) and a modulus of elasticity of $205 \mathrm{GPa}$. As for the concrete, the stress versus strain curve was defined according to the Brazilian Standard specification for reinforced concrete [12], using a parabolic curve defined with the expression shown in (Equation 5). Figure 6 shows the stress versus strain curves considered for the concrete chords and for the steel chord.

$\sigma_{c}=f_{c k}\left[1-\left(1-\varepsilon_{c} / 0.002\right)^{2}\right]$ 


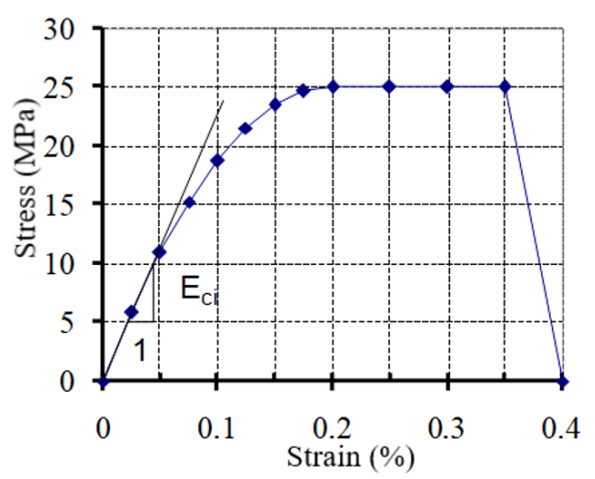

a) Concrete elements

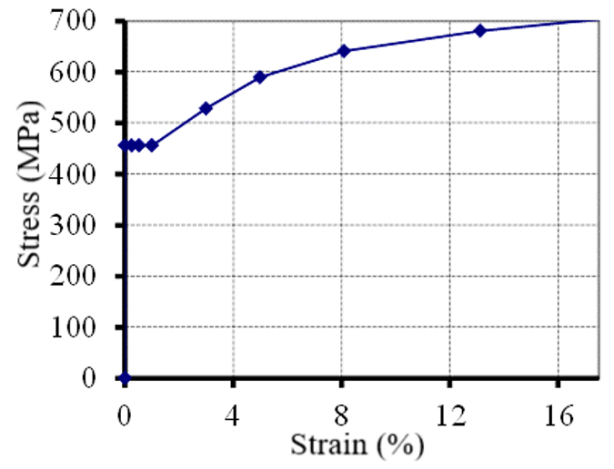

b) Steel elements

Figure 6. Stress versus strain curves used as materials properties.

The steel reinforcing bars were modeled considering a perfect elastoplastic behavior. The shear connectors steel was modeled considering a bilinear behavior with yielding strength equal to $250 \mathrm{MPa}$ and the ultimate strength equal to $400 \mathrm{MPa}$.

The load was applied to nodes located on the concrete slab, allowing the Ansys program to control the load increase during the analyses automatically. Minimum and maximum increments limit were imposed equal to $1 \%$ and $10 \%$ of the total estimated load, respectively. A large-displacement analysis was adopted since it is an efficient method to solve non-linear equations, and the program automatically defines the convergence criteria.

\section{EXPERIMENTAL PROGRAM}

\section{Test assembly}

The tests with Truss 1 occurred in the Laboratory of Structures "Professor Altamiro Tibiriçá Dias" at the Department of Civil Engineering of the Universidade Federal de Ouro Preto. Figure 7 shows an overall image of the test assembly and loading scheme. Three reinforcing bars connected the specimen to the lateral containment frames to avoid tipping during the tests. The load application was performed using three hydraulic actuators with a load capacity of $500 \mathrm{kN}$. The actuators were fixed directly to the reaction frame and to a pinned load cell that guarantees verticality in the loading. Rectangular plates were placed below the load cell at the slab concrete to minimize the contact region compression stress, avoiding concrete local crushing.

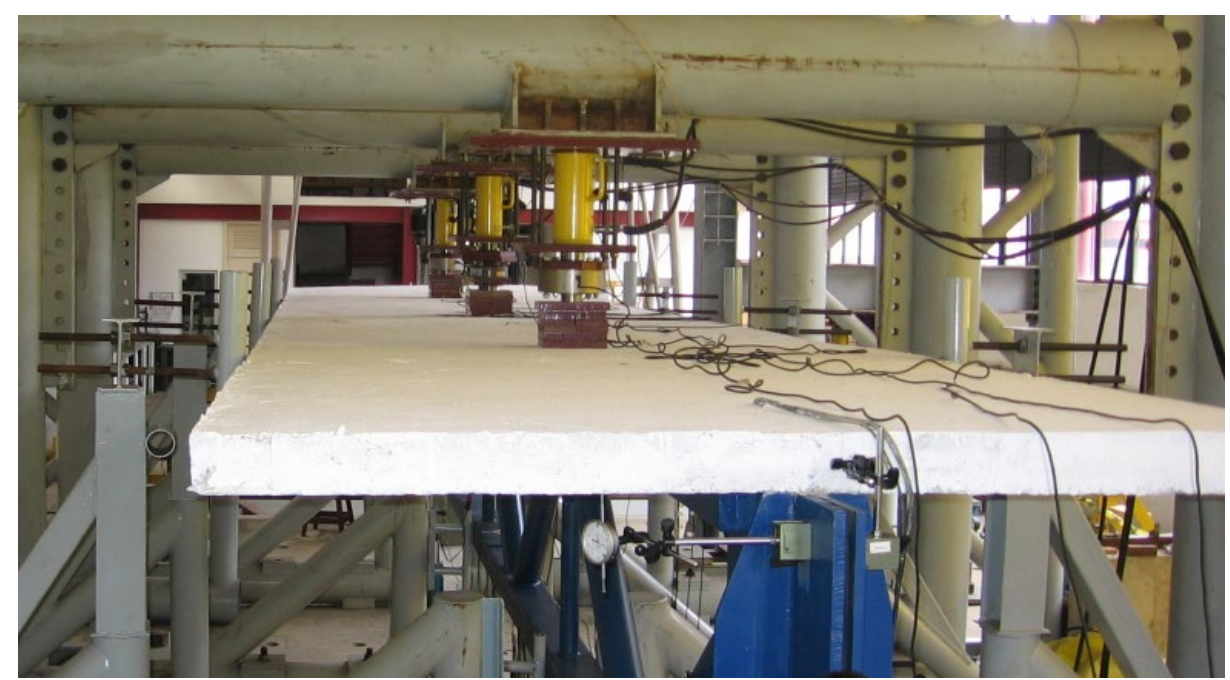

Figure 7. Overall view of the test assembly. 
Strain gages were used to measure strains, with eighteen unidirectional strain gages for linear strain and four $45^{\circ}$ rosettes strain gages. Displacements were measured with five LVDTs - "Linear Variable Displacement Transducers" and with seven analog deflectometers. The instrumentation positioning was defined based on the numerical analysis results. An automatized computer-controlled data acquisition and monitoring system was used.

\section{RESULTS AND DISCUSSIONS}

\section{Load versus Displacement}

Figure 8 illustrates the Load versus Displacement curves obtained in the vertical direction in the middle of the span, demonstrating a good correlation of the experimental and numerical results. The graph indicates load values that are, theoretically, the shear connection strength limit, the elastic limit (beginning of the yielding of the lower chord by tension), and the plastic limit (total yielding of the lower chord by tension). As previously reported, the results using formulations of standards and literature indicate the possibility of failure in the shear connection before the chord yielding. The maximum load reached, both in the numerical analysis and in the experiment $(\approx 268.0 \mathrm{kN})$, was slightly higher than the connection load capacity limit $(253.0 \mathrm{kN})$. For Truss 2, designed with the modification in the shear connection to guarantee a total interaction, the plastic limit load of $322.0 \mathrm{kN}$ was reached.

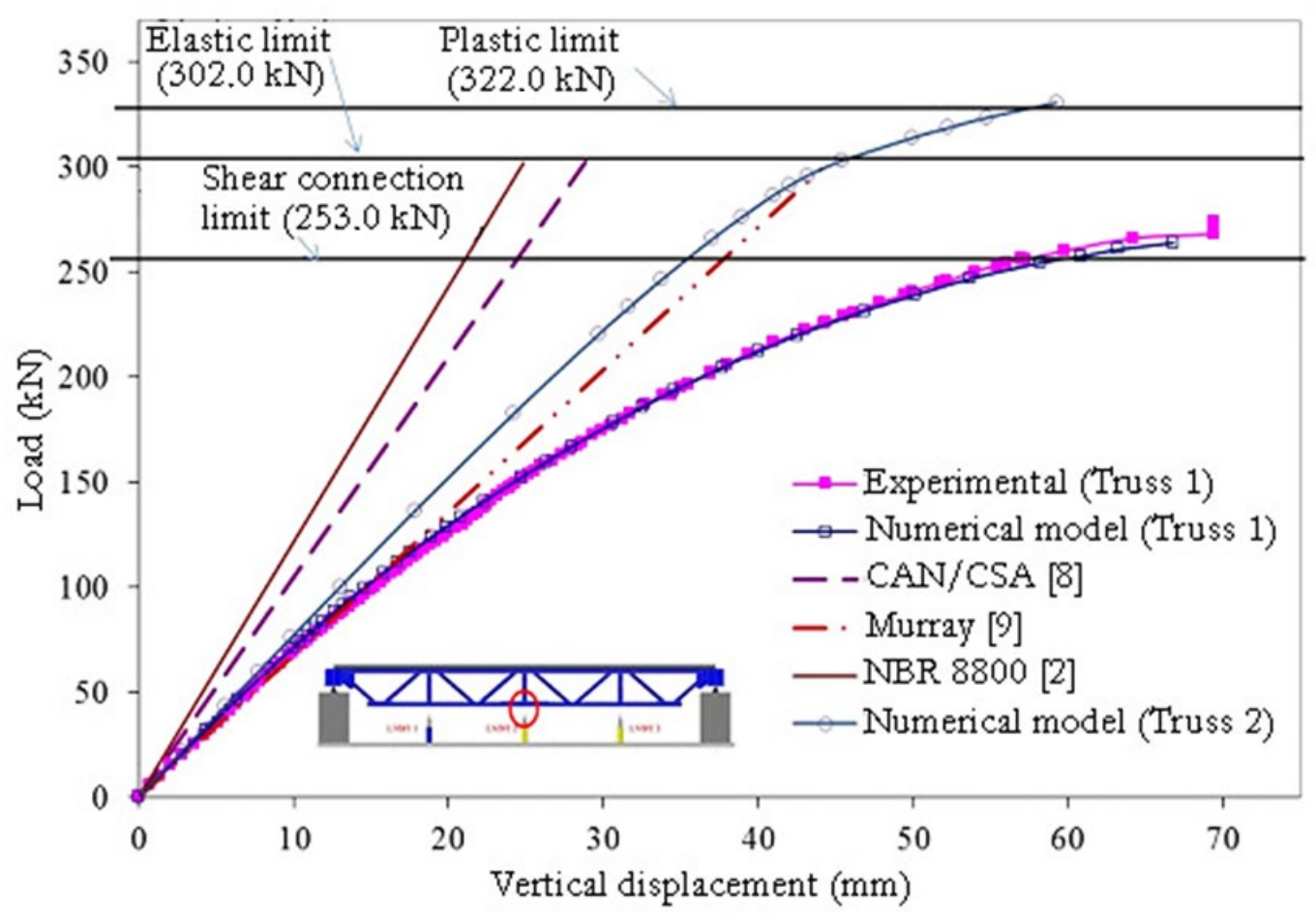

Figure 8. Comparison of load versus displacement curves.

The nonlinearity in the results from the initial loads is observed for Truss 1 due to excessive deformations in the connectors because of the upper chord wall great flexibility, where the connectors were welded (Figure 9). The top face wall has a thickness of $4.8 \mathrm{~mm}$ and a width of $150 \mathrm{~mm}$, which are measures within limits for a compressed member $\left(b / t=1,14 \sqrt{E / f_{y}}<b / t \sqrt{E / f_{y}}\right.$ lim $)$ according to Brazilian standard [2]. Since the connector has a length of $80 \mathrm{~mm}$, its stability depends entirely on the chord upper face stiffness. The modification in the shear connection in Truss 2 ensures greater stiffness and greater strength to the structure, as the numerical results indicate. 


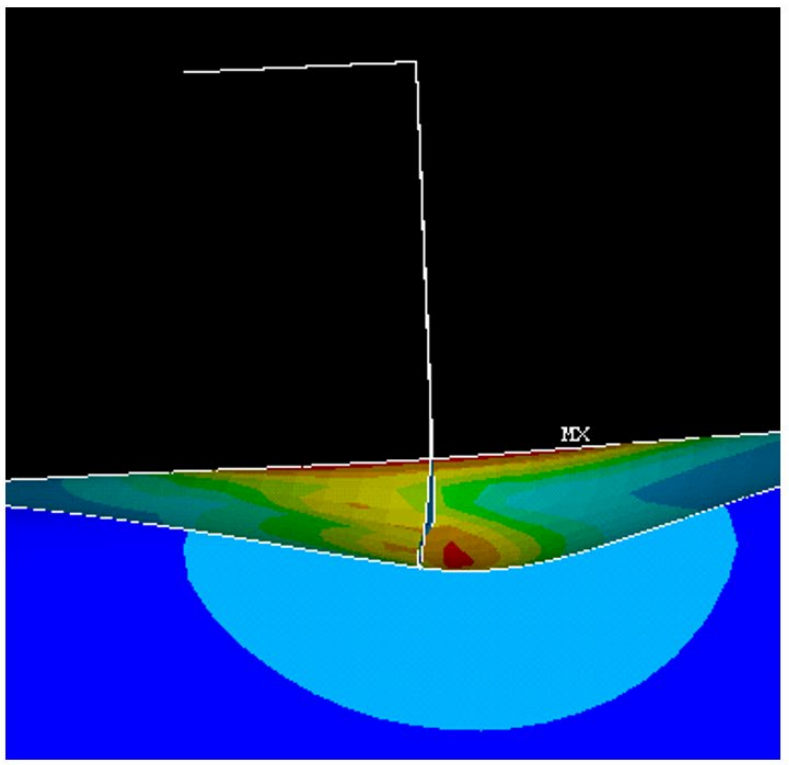

a) Numerical model

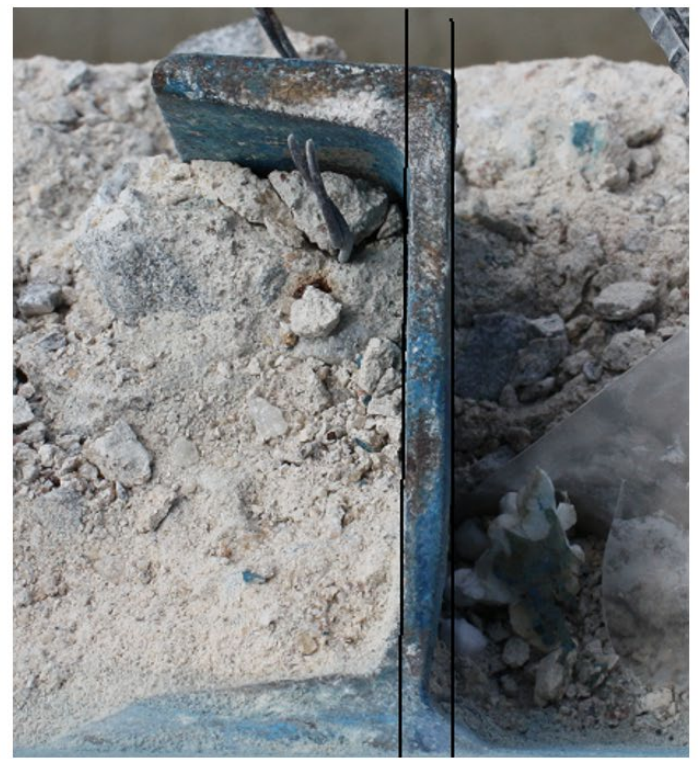

b) Experimental test

Figure 9. Deformation of connector due to low stiffness of the top face of the chord.

The load limits from formulations of standards and literature, indicated in Figure 8, were obtained considering the effective moments of inertia calculated using Equations 1, 2, and 4 referring respectively to the specifications of the Brazilian Standard [2], Canadian Standard [8] and Murray et al. [9]. There was a more significant divergence with the experimental results when assessing the Brazilian standard [2] and a better approximation when considering the recommendations of Murray et al. [9]. Even in this last case, a good correlation was observed only for the initial loads of Truss 1. A better approximation of the effective moment of inertia values obtained using Equations 1 and 2 is possible whenever the relationship between the span length and the height of the truss $(L / h)$ is greater than 15 and in the presence of more rigid shear connectors, as it observed in other similar studies [13], [14]. In such studies, the shear connection was designed with a "Perfobond" connector, considered more rigid. For the truss evaluated in this paper, the relation length-height is $(L / h=10)$, and the connector is more flexible. Thus, a better approximation of the results is obtained using Equation 4. The shear connection greater deformability influenced the results, increasing the relative horizontal sliding between the slab and the upper chord, measured experimentally by a displacement transducer. Numerical analyses also showed the relative displacement, as can be observed in Figure 10. This relative horizontal sliding indicates the loss of interaction between the upper chord and the slab, characterizing a partial interaction type.

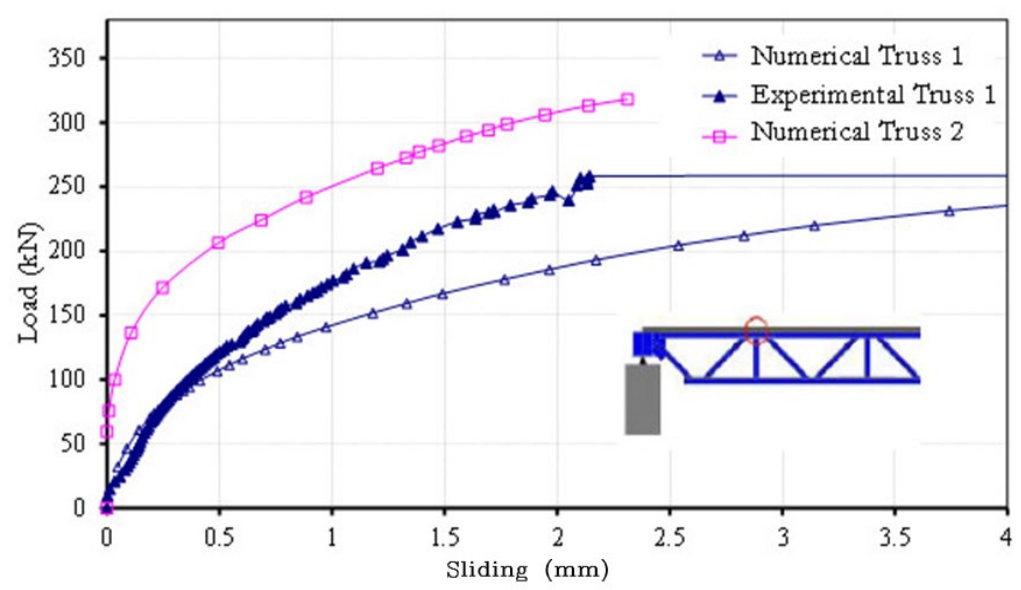

Figure 10. Horizontal sliding between the slab and the upper chord. 


\section{Load versus Deformation}

The study compared the linear deformations observed in the lower face of the lower chord (Figure 11), von Mises deformations in the shear connector near the support (Figure 12), and the region of the truss inferior node without reinforcement (Figure 13). The numerical result concerning the lower chord presented a good approximation with the experimental results. In Truss 2, a linear behavior is observed up to the load corresponding to the chord yielding (indicated by the vertical line in the graphs and equal to $280 \mathrm{kN}$ ), which matches the analytically calculated elastic limit load shown in Figure 8.

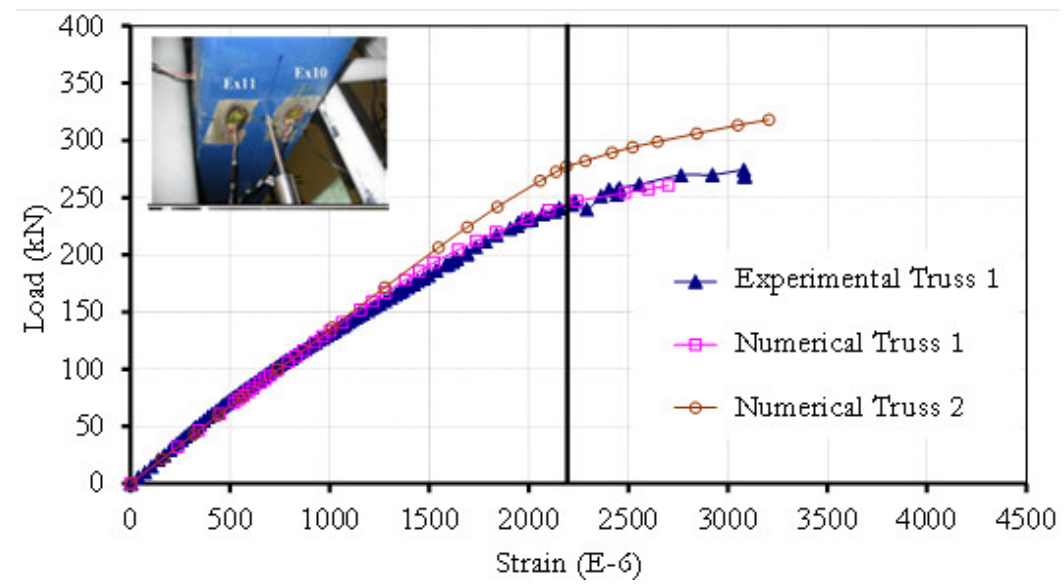

Figure 11. Strains in the lower face of the lower chord.

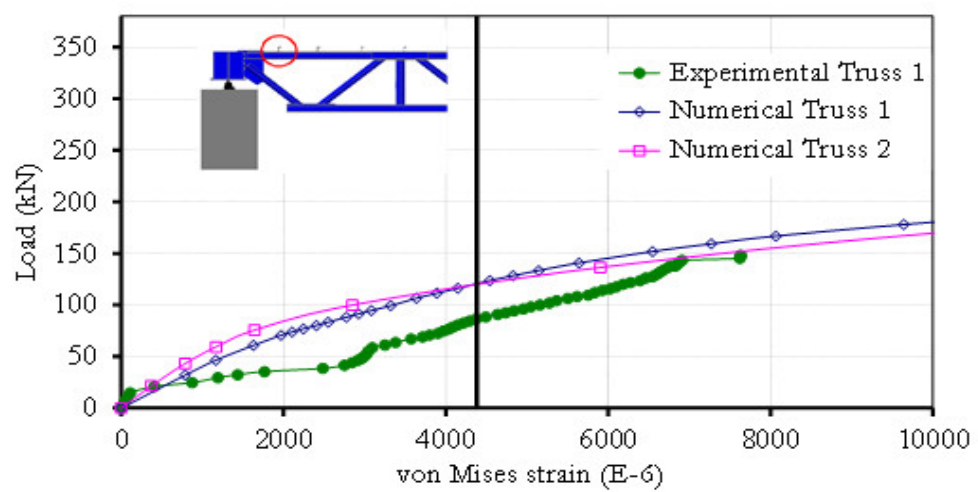

Figure 12. Strains of the shear connector.

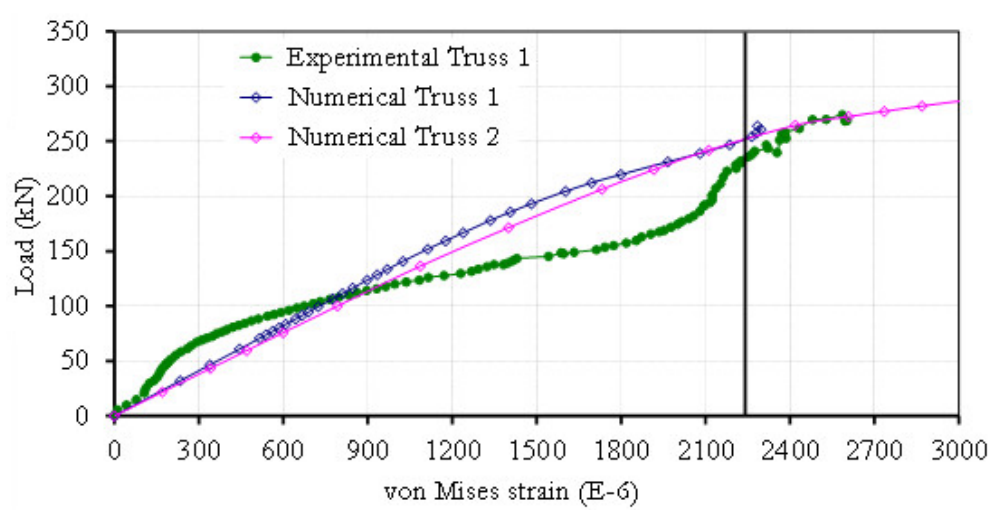

Figure 13. Strains in the region of one of the lower nodes. 
As shown in Figure 11, the lower chord strains indicate that this member is under tension. In the experimental analyses performed, the upper chord strains were also measured (Figure 14). The strains in the upper chord indicate that this member is under compression.

For the shear connector (Figure 12), the curve obtained with the numerical results presented a slightly different shape from the experimental results, which may be explained due to localized effects. After the yielding limit (indicated by the vertical line), there was a better approximation of the results. The numerical results of Truss 2 are similar to the results obtained from Truss 1 .

In the region where the diagonals are connected to the lower chord (Figure 13), in which there were no reinforcement plates, differences in numerical and experimental results are also observed, with an approximation of values for maximum loads.
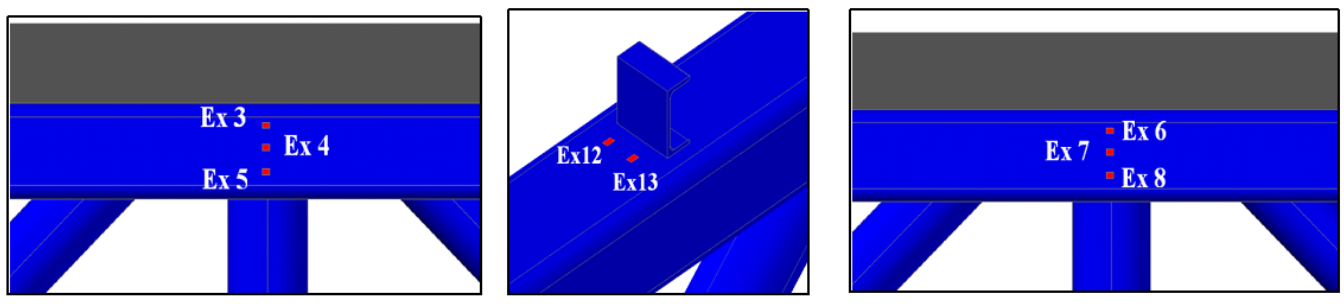

(a) Position of the strain gages

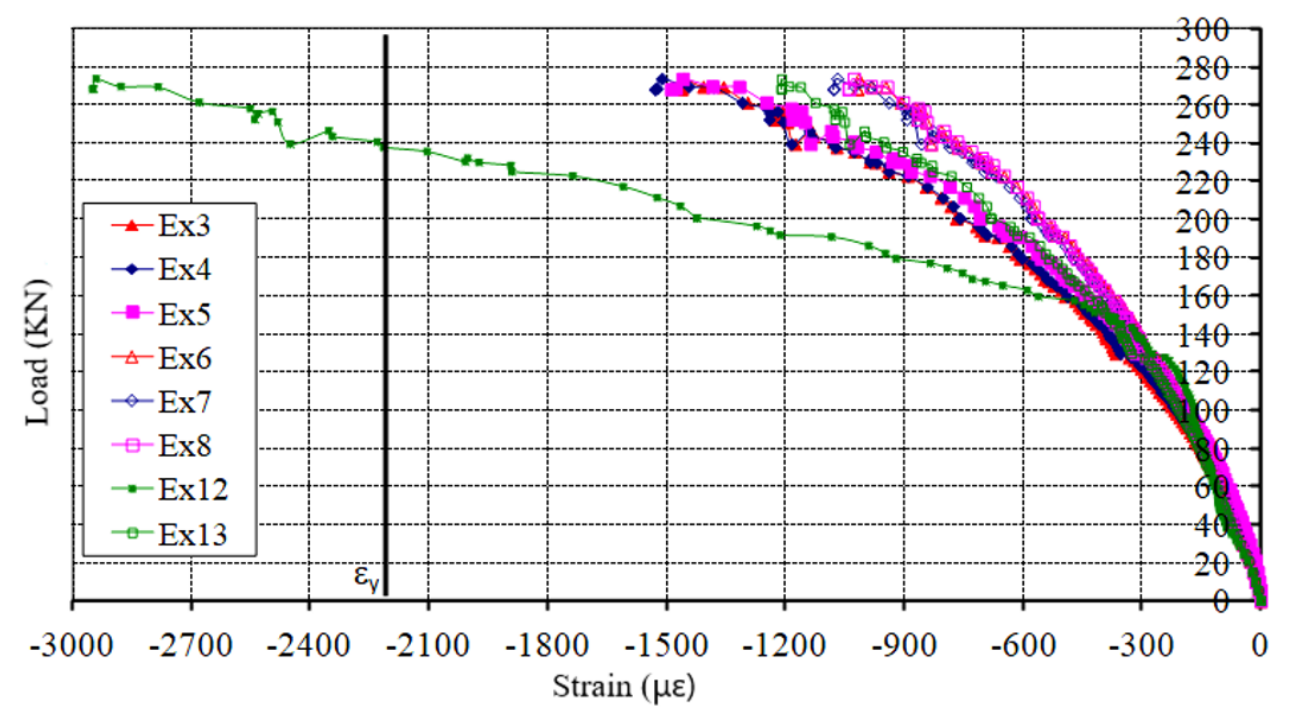

(b) Load versus strain curves for each strain gage

Figure 14. Strains measured in the upper chord.

\section{Maximum stress observed in truss members.}

Figure 15 and Figure 16 show the stress field (von Mises total stress) for the steel members, considering the analyses maximum load. In Truss 1 (Figure 15), the stresses with values higher than the material yield limit were concentrated along the upper chord in the regions where the shear connectors are attached. There was a plastification in the area around the chord connection, in the diagonal and in the upright posts in the central node region, which were added to the plastification in the connector. Thus, the plastification is more evident in this member region. Plastification can also be found in the regions at the most demanded diagonal members ends, in the lower chord, around the connecting node without reinforcement, and at the middle of the span along the lower face. 


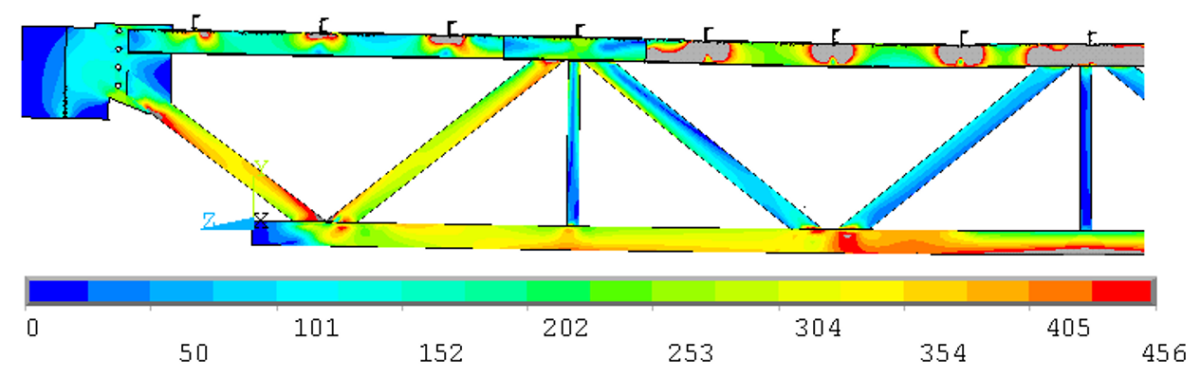

a) Lateral view
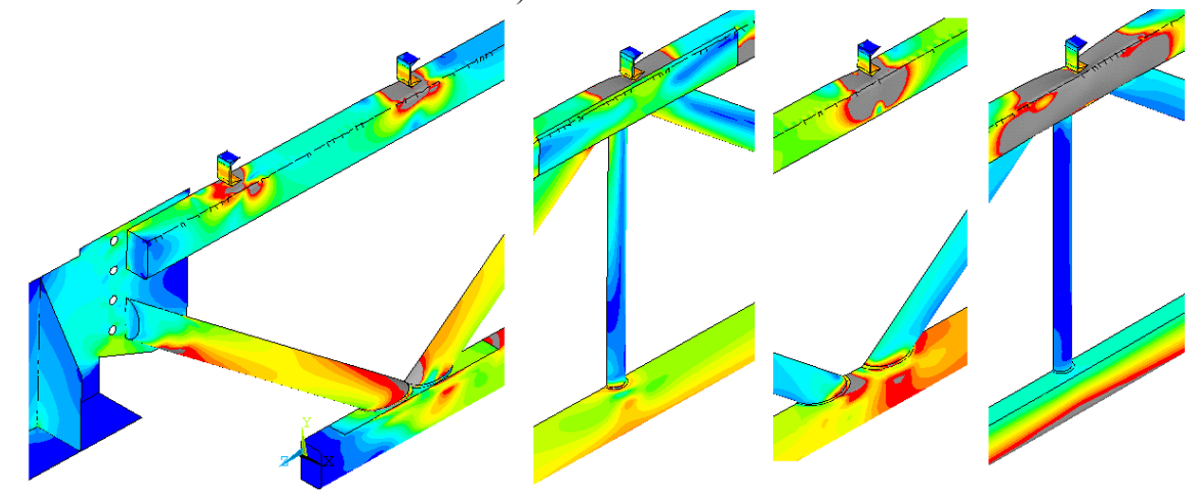

b) $3 \mathrm{D}$ view

Figure 15. von Mises stresses in MPa for the steel members of Truss 1.

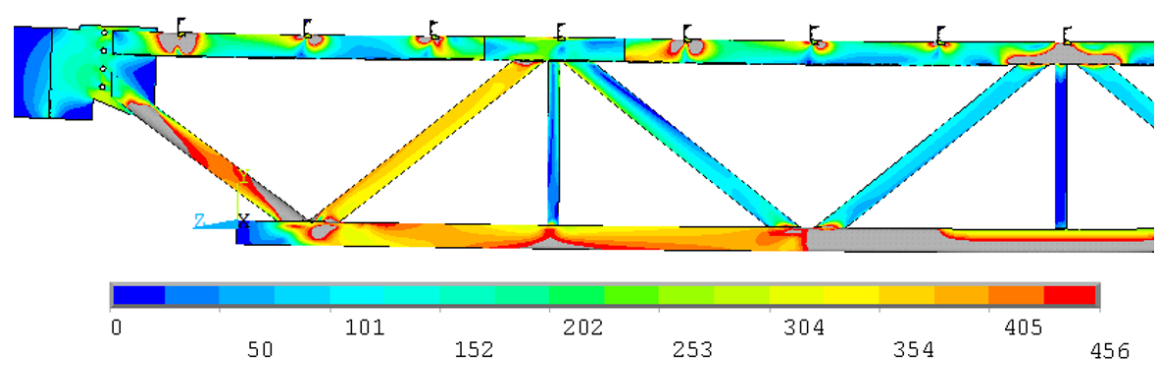

a) Lateral view

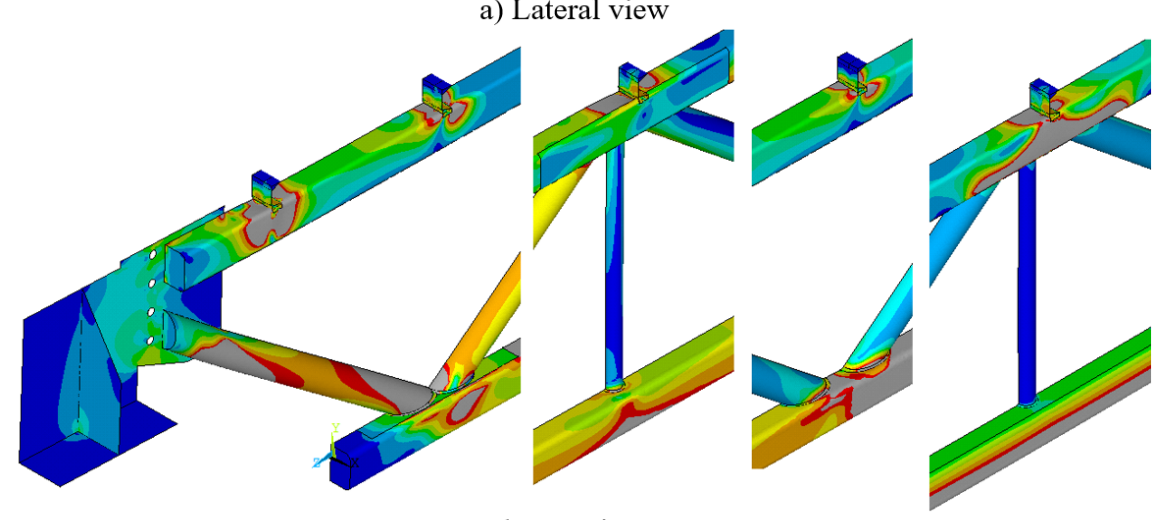

b) $3 \mathrm{D}$ view

Figure 16. von Mises stresses in MPa for the steel members of Truss 2.

For Truss 2 (Figure 16), the yield limit was exceeded in the lower chord along the entire central span section and concentrated in the nodes and in the connectors regions. This occurs with less intensity in Truss 1. Plastification is also observed at the ends of the most demanded diagonals and in the upper chord, in the region of the connecting nodes, in the middle of the span, and the at the support. 
Along the lower chord and in the middle of the span, the deformations from the structure bending results the member under tension. In the connecting nodes region and in the ends of the diagonal members, the plastification is due to the localized effects of the connection between members in the tubular section. Those plastifications were considered in the analyses via the formulations of standards and literature, used to obtain the strength of tubular connections without reinforcement.

Figure 17 and Figure 18 display the transverse stresses measured along the top and lower slab faces for maximum loads. Because of the structure bending, compressive stress predominates on the top face, and tension stress can be seen on the lower face. More significant efforts were observed in the regions above the connecting nodes, among the upper chord, diagonals, and upright posts, indicating the existence of concentrated moment loads. These efforts, added to the global bending of the slab, caused stress concentration in the middle of the span. The shear connectors also caused stress concentration on the slab as it can be observed, mainly, along the lower face of the Truss 2 slab. For this case, there was a stress concentration in the region near to the top node, close to the support. Its value decreased as it moved away from the node. Truss 1, characterized by a partial interaction type, has more efforts developed, resulting from the global bending. Truss 2 has higher efforts and greater stresses were localized in the regions of connecting nodes and in the region where the connectors were positioned.

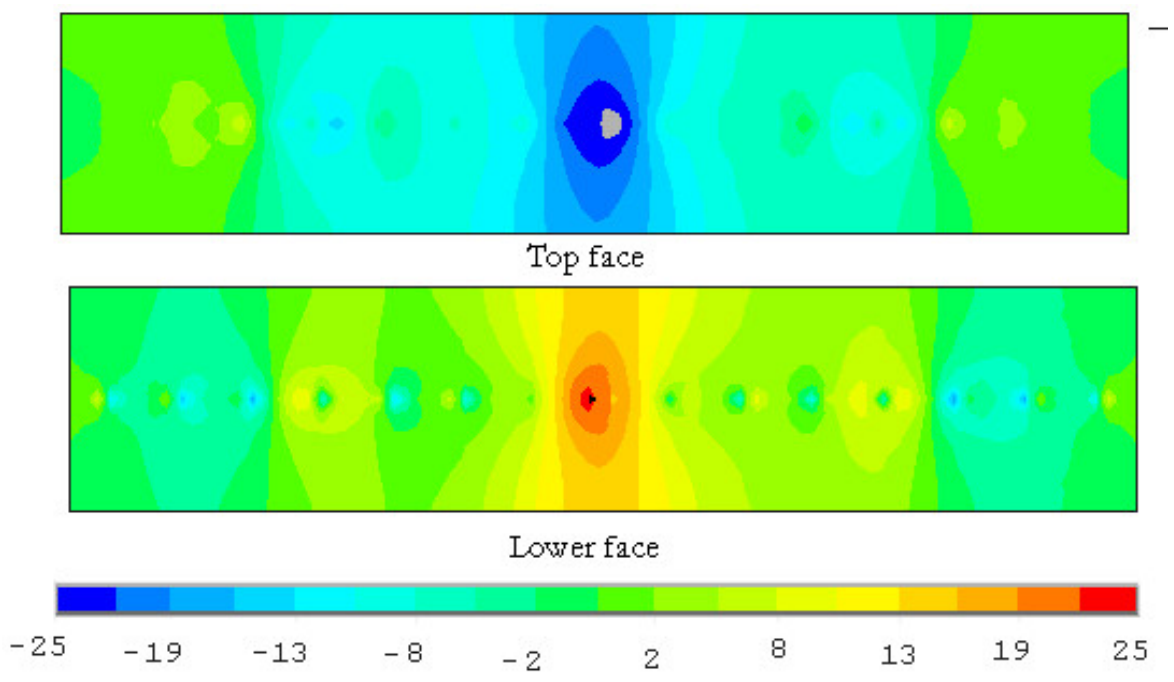

Figure 17. Transverse stresses in MPa measured in the slab faces of Truss 1.

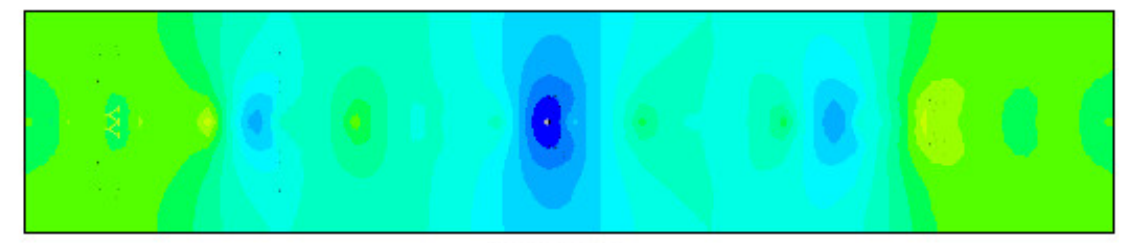

Top face

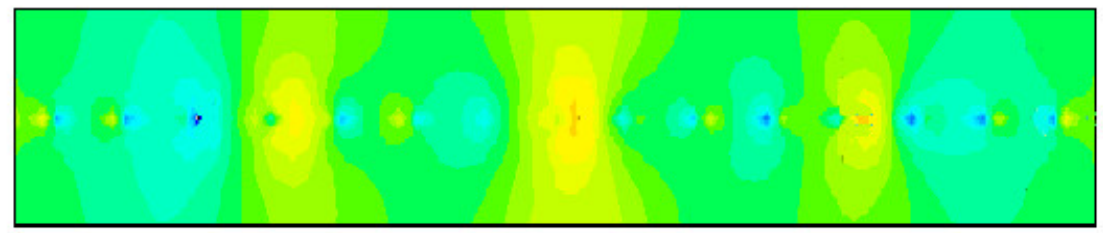

Lower face

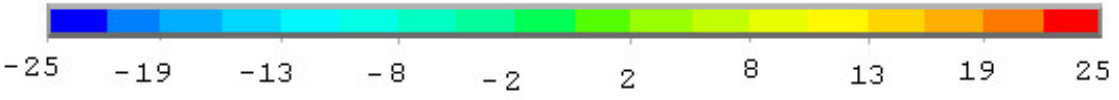

Figure 18. Transversal stresses in MPa measured in the slab faces of Truss 2. 
In both trusses, the position of the neutral axis is inside the slab. The average strains in the slab height were measured from strain gage localized in the upper and lower slab faces and in the steel reinforcing bars. In Truss 1, the neutral axis was initially positioned $20 \mathrm{~mm}$ from the contact base between the upper chord and the slab (Figure 19). With the load increasing, it migrated to a $45 \mathrm{~mm}$ position from the base for the maximum load of $264 \mathrm{kN}$. In Truss 2, the neutral axis was positioned $35 \mathrm{~mm}$ from the base for the maximum load of $368 \mathrm{kN}$.

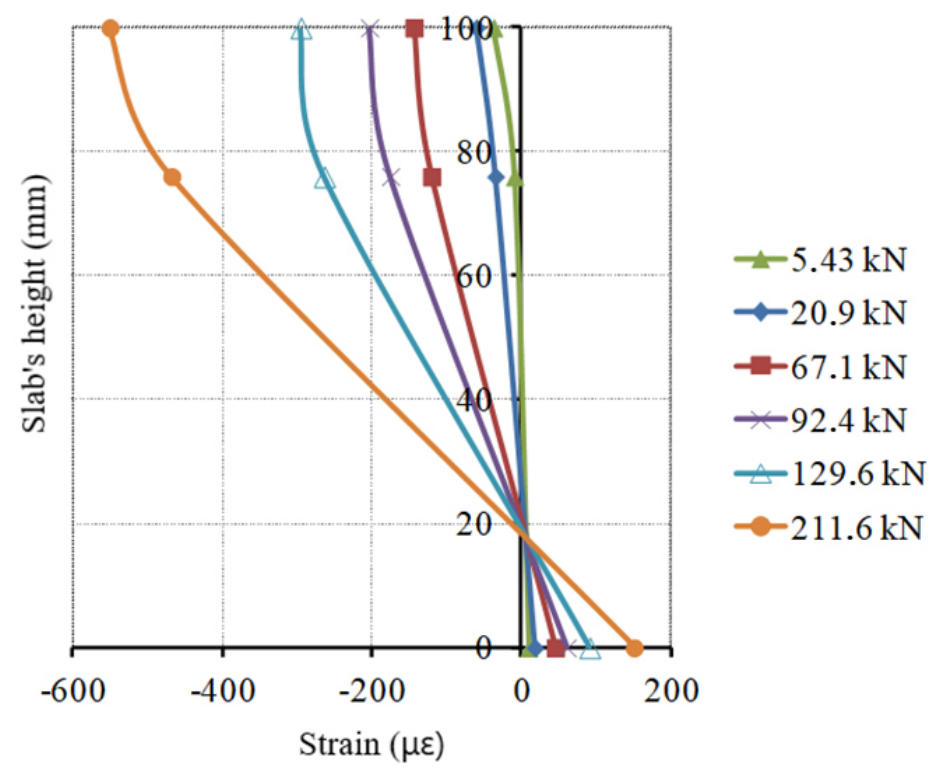

Figure 19. Strains in the slab height.

As shown in Figure 11 and Figure 14, the lower chord is under tension, and the upper chord is under compression, indicating the existence of a neutral axis in Truss 1. A second neutral axis is also observed in the slab, as shown in Figure 19. Two neutral axes characterize a steel-concrete partial interaction type, with sliding in the steel-concrete interface, supported by the shear connector that presents plastic deformation (Figure 9).

\section{CONCLUSIONS}

The study evaluated composite trusses from experimental and numerical analyses. Comparisons of these results with standards and literature analytical expressions were performed to verify the influence of the shear connection in the truss bending behavior.

Truss 1 allowed a good approximation between experimental and numerical results. Regarding the shear connection strength, the possibility of connection failure before the chord yielding was observed. The maximum loads obtained, both in the numerical and experimental analysis, were slightly higher than the load capacity limit calculated for the shear connection. With the modification in the shear connectors to guarantee the total interaction in Truss 2 , a standard plastic limit load was achieved.

Experimental and numerical analyses indicate the influence of the upper chord wall flexibility on the deformability of the shear connection. This influence is more observed in Truss 1. Even with the shear connection change in Truss 2, a good correlation between the numerical results and those obtained according to the standard recommendations is still not possible. For the trusses evaluated, with the relationship between span length and height $(L / h)$ equal to 10 , better results were obtained according to Murray et al. [9], where the effective moment of inertia is calculated considering the $L / h$ ratio.

The von Mises stresses on the steel members of Truss 1, shows a larger plastification in the upper chord region where the shear connectors were fixed, which made the structure very deformable. In Truss 2, the largest plastification occurred along the lower chord in the middle of the span, where there was total plastification of the member section, as recommended by the standards. 


\section{ACKNOWLEDGEMENTS}

Special thanks to CAPES, CNPQ, and FAPEMIG, for the financial support in the preparation of this work; to Vallourec for the supply of the test prototypes, to the IFMG and, mainly to UFOP for the logistical and financial support in conducting this study; and finally, to the team of the UFOP Structures Laboratory for the availability and direct support in the execution of the experiments.

\section{REFERENCES}

[1] J. Wardenier, Y. Kurobane, J. A. Packer, D. Dutta, and N. Yeomans, Design Guide for Circular Hollow Section (CHS) Joints Under Predominantly Static Loading. Germany: Comité International pour le Développemente et l'Étude de la Construction Tubulaire, 1991.

[2] Associação Brasileira de Normas Técnicas, Projeto de Estruturas de Aço e Estruturas Mistas de Aço e Concreto de Edifícios, ABNT NBR 8800, 2008.

[3] E. Y. L. Chien and J. K. Ritchie, "Composite open web steel joints and trusses," in Design and Construction of Composite Floor Systems. Ontario: Canadian Institute of Steel Construction, 1984, ch. 5.

[4] ASCE - Task Committee on Design Criteria for Composite Structures in Steel and Concrete, "Proposed specification and commentary for composite joints and composite trusses," J. Struct. Eng., vol. 122, no. 4, pp. 350-35, 1996.

[5] J. Machacek and M. Cudejko, "Composite steel and concrete bridge trusses," J. Eng. Struct., vol. 33, no. 12, pp. 3136-3142, Dec 2011, http://dx.doi.org/10.1016/j.engstruct.2011.08.017.

[6] A. Bouchair, J. Bujnak, and P. Duratna, "Connection in steel-concrete composite truss," Procedia Eng., vol. 40, pp. 96-101, 2012, http://dx.doi.org/10.1016/j.proeng.2012.07.062.

[7] European Committee for Standardization, Eurocode 4 - Design of Composite Steel and Concrete Structures, Part 2: Composite Bridges, DD ENV 1994-2:2001, 2001.

[8] Canadian Standard Association, Limit States Design of Steel Structures, CAN/CSA-S16-01, 2003.

[9] T. M. Murray, D. Allen, and E. Ungar, Floor Vibrations Due to Human Activity (Steel Design Guide Series 11). Chicago: American Institute of Stell Construction, 1997.

[10] Ansys, User's Manual for Revision 11. Houston, PA: Swanson Analysis Systems Inc., 2007.

[11] A. M. S. Freitas, F. C. Mendes, and S. Steves, "Numerical analysis of hollow section T joints with residual stresses," in Proc. XXXIII Jorn. Sudam. Ing. Estruct., Santiago, Chile, 2008.

[12] Associação Brasileira de Normas Técnicas, Projeto de Estruturas de Concreto - Procedimento, ABNT NBR $6118,2014$.

[13] J. D. Martins and A. M. S. Freitas, "Participação da laje de concreto na resistência a esforços em composite trusses," in $A n .53^{\circ}$ Cong. Bras. Concr., 2011.

[14] J. D. Martins, A. M. S. Freitas, “Análise em elementos finitos de composite trusses com conexões tubulares,” in XXV Jorn. Sulam. Eng. Estrut., Rio de Janeiro, 2012.

Author contributions: JDM: conceptualization, numerical model, formal analysis, data curation, writing; SEPJ: conceptualization, experimental model; EMX and LHAN: formal analysis, data curation, revision; AMCS: funding acquisition, supervision.

Editors: José Luiz Antunes de Oliveira e Sousa, Guilherme Aris Parsekian. 